Poetry

Published September 5, 2019

\title{
The Sloth
}

AUTHORS

Michael M. Lederman and Daniel R. Kuritzkes
DOI

10.20411/pai.v4i2.296

I nearly saw a three-toed sloth

I really hoped to see one

But as I crept up on the beast

He sped off like a demon

How did this lazy fellow do it?

My legs were gelled, encased in suet

Insensate speed was needed now

That wily sloth could sprint, and how!

I called upon my last reserves

To stay with him through streams and curves

He would not give this race a rest

Just like those hounds of Budapest

His limbs a blur, his eyes agleam

His ears pressed back, his goggles seem

To mask his real intent, his dream

To master speed and be the Dean

of hustle.

\section{ABOUT THE AUTHORS}

Michael Lederman is a physician scientist in Cleveland, Ohio. His granddaughter loves sloths. Dr. Kuritzkes is a physician scientist in Boston, Massachusetts. He hopes his granddaughter will grow to appreciate sloths.

\section{FOOTNOTES}

Submitted May 24, 2019| Accepted August 20, 2019 | Published September 5, 2019

\section{COPYRIGHT}

Copyright $\odot 2019$ Pathogens and Immunity

This is an open-access article distributed under the terms of the Creative Commons Attribution 4.0 International License. 